\title{
Cell Type-Specific Expression of a Genetically Encoded Calcium Indicator Reveals Intrinsic Calcium Oscillations in Adult Gonadotropin-Releasing Hormone Neurons
}

\author{
Christine L. Jasoni, ${ }^{1}$ Martin G. Todman, ${ }^{1}$ Max M. Strumia, ${ }^{2}$ and Allan E. Herbison ${ }^{1}$ \\ ${ }^{1}$ Centre for Neuroendocrinology and Department of Physiology, and ${ }^{2}$ Department of Mathematics, University of Otago School of Medical Sciences, Dunedin \\ 9054, New Zealand
}

\begin{abstract}
The gonadotropin-releasing hormone $(\mathrm{GnRH})$ neurons exhibit a unique pattern of episodic activity to control fertility in all mammals. To enable the measurement of intracellular calcium concentration $\left(\left[\mathrm{Ca}^{2+}\right]_{\mathrm{i}}\right)$ in adult $\mathrm{GnRH}$ neurons in situ, we generated transgenic mice in which the genetically encodable calcium indicator ratiometric Pericam was expressed by $\sim 95 \%$ of GnRH neurons. Real-time monitoring of $\left[\mathrm{Ca}^{2+}\right]_{\mathrm{i}}$ within adult male $\mathrm{GnRH}$ neurons in the acute brain slice revealed that $\sim 70 \%$ of GnRH neurons exhibited spontaneous, $10-15$ $s$ duration $\left[\mathrm{Ca}^{2+}\right]_{\mathrm{i}}$ transients with a mean frequency of 7 per hour. The remaining $30 \%$ of GnRH neurons did not exhibit calcium transients nor did a population of non-GnRH cells located within the lateral septum that express Pericam. Pharmacological studies using antagonists to the inositol-1,4,5-trisphosphate receptor $\left(\mathrm{InsP}_{3} \mathrm{R}\right)$ and several calcium channels, demonstrated that $\left[\mathrm{Ca}^{2+}\right]_{\mathrm{i}}$ transients in $\mathrm{GnRH}$ neurons were generated by an InsP ${ }_{3} \mathrm{R}$-dependent store-release mechanism and were independent of plasma membrane ligand- or voltage-gated calcium channels. Interestingly, the abolition of action potential-mediated transmission with tetrodotoxin reduced the number of $\left[\mathrm{Ca}^{2+}\right]_{\mathrm{i}}$ transients in $\mathrm{GnRH}$ neurons by $50 \%(p<0.05)$, suggesting a modulatory role for synaptic inputs on $\left[\mathrm{Ca}^{2+}\right]_{\mathrm{i}}$ transient frequency. Using a novel transgenic strategy that enables $\left[\mathrm{Ca}^{2+}\right]_{\mathrm{i}}$ to be examined in a specific neuronal phenotype in situ, we provide evidence for spontaneous $\left[\mathrm{Ca}^{2+}\right]_{\mathrm{i}}$ fluctuations in adult $\mathrm{GnRH}$ neurons. This represents the initial description of spontaneous $\left[\mathrm{Ca}^{2+}\right]_{\mathrm{i}}$ transients in mature neurons and shows that they arise from an $\mathrm{Ins}_{3} \mathrm{R}$-generating mechanism that is further modulated by synaptic inputs.
\end{abstract}

Key words: calcium; $\mathrm{IP}_{3} \mathrm{R} ; \mathrm{GnRH}$; transgenic; Pericam; inositol

\section{Introduction}

Intracellular calcium concentration $\left(\left[\mathrm{Ca}^{2+}\right]_{\mathrm{i}}\right)$ controls many diverse cellular processes and is regulated in a highly variable manner across cell types and subcellular domains (Berridge et al., 2003). Within neurons, short $(<1 \mathrm{~s})$ duration $\left[\mathrm{Ca}^{2+}\right]_{\mathrm{i}}$ transients can be evoked by synaptic activation and are best characterized in dendritic spine heads where they result from NMDA receptor and/or voltage-gated calcium channel (VGCC) activation (Jaffe et al., 1992; Markram et al., 1995; Koester and Sakmann, 1998; Nakamura et al., 1999; Yuste et al., 1999; Kovalchuk et al., 2000; Sabatini et al., 2002). In addition, the slower release of calcium from intracellular stores has emerged as yet another avenue through which $\left[\mathrm{Ca}^{2+}\right]_{\mathrm{i}}$ can be elevated (Nakamura et al., 1999, 2002; Ross et al., 2005; Verkhratsky, 2005) in neurons. The physiological roles and mechanisms underlying these slower $\left[\mathrm{Ca}^{2+}\right]_{\mathrm{i}}$ transients are less well characterized.

\footnotetext{
Received Aug. 18, 2006; revised Dec. 14, 2006; accepted Dec. 15, 2006.

This work was supported by the Wellcome Trust and the Biotechnology and Biological Sciences Research Counci of the United Kingdom. We thank Dr. Atsushi Miyawaki for the kind provision of ratiometric Pericam.

Correspondence should be addressed to Allan E. Herbison, Centre for Neuroendocrinology, Department of Physiology, University of Otago School of Medical Sciences, P.0. Box 913, Dunedin 9054, New Zealand. E-mail: allan.herbison@stonebow.otago.ac.nz.

DOI:10.1523/JNEUROSCI.3579-06.2007

Copyright $\odot 2007$ Society for Neuroscience $\quad$ 0270-6474/07/270860-08\$15.00/0
}

In terms of episodic neuronal activity, hypothalamic gonadotropin-releasing hormone ( $\mathrm{GnRH})$ neurons are an interesting phenotype. These cells secrete GnRH from their nerve terminals in a pulsatile manner comprised of $4-5$ min bursts of activity every $30-60 \mathrm{~min}$ to control fertility (Terasawa, 2001; Moenter et al., 2003; Herbison, 2006). The mechanisms underlying this behavior are unknown, and technical issues have precluded the investigation of this neuronal phenotype in situ. Studies on immortalized cell lines and olfactory placode cultures have shown that immature GnRH neurons exhibit cytosolic calcium fluctuations arising from calcium entry through L-type VGCC, after spontaneous membrane depolarization events (Krsmanovic et al., 1992; Charles and Hales, 1995; Terasawa et al., 1999; Van Goor et al., 1999a,b; Moore and Wray, 2000). However, many neuronal cell types exhibit $\left[\mathrm{Ca}^{2+}\right]_{\mathrm{i}}$ oscillations during embryogenesis (Ben-Ari and Spitzer, 2004), and the relevance of these findings to adult GnRH neurons that exhibit episodic activity is unknown.

The aim of the present study was to establish whether adult GnRH neurons in their native environment exhibit spontaneous $\left[\mathrm{Ca}^{2+}\right]_{i}$ changes. Monitoring $\left[\mathrm{Ca}^{2+}\right]_{\mathrm{i}}$ with fluorescent indicator molecules has proved to be an invaluable approach (MaleticSavatic et al., 1999; Tsien, 2003). However, the nonspecific bulk loading of cells with membrane-permeant calcium indicator dyes 
can be difficult in slices of adult brain, often requiring potentially harmful loading procedures, and is not suited for long-term recordings. The problem of loading GnRH neurons is exacerbated further, because their cell bodies are scattered throughout the basal forebrain. To overcome these issues, we used a GnRH promoter strategy to generate transgenic mice in which the calcium indicator ratiometric Pericam (Nagai et al., 2001) is targeted to GnRH neurons. This has enabled the investigation of $\left[\mathrm{Ca}^{2+}\right]_{i}$ in adult GnRH neurons in situ. We show here that the majority of adult GnRH neurons exhibit spontaneous fluctuations in $\left[\mathrm{Ca}^{2+}\right]_{\mathrm{i}}$ deriving from intracellular store mechanisms. The findings demonstrate that adult GnRH neurons in situ possess an intrinsic oscillatory mechanism and provide evidence for spontaneous $\left[\mathrm{Ca}^{2+}\right]_{\mathrm{i}}$ transients in adult neurons.

\section{Materials and Methods}

Animals. All experimentation was approved by the University of Otago Animal Welfare and Ethics Committee under Application 66/02. Transgenic GnRH-Pericam mice (C57BL6/J × CBA/Ca) were maintained under a $12 \mathrm{~h}$ light/dark cycle (lights on at 7:00 A.M.) with food and water available ad libitum.

Generation of GnRH-Pericam mice. The GnRH-Pericam mouse was generated in the same manner as reported previously (Skynner et al., 1999) using a $\sim 12 \mathrm{~kb}$ transgene incorporating all the introns and exons of the GnRH gene, $5.5 \mathrm{~kb}$ of upstream ( $\left.5^{\prime}\right)$ and $3.5 \mathrm{~kb}$ of downstream $\left(3^{\prime}\right)$ flanking sequence, and a SmaI site engineered by site-directed mutagenesis in exon II between sequences encoding amino acids 2 and 3 of the $\mathrm{GnRH}$ decapeptide (see supplemental data, available at www.jneurosci.org as supplemental material). An expression cassette consisting of (in $5^{\prime}$ to $3^{\prime}$ order) a synthetic intron, the ratiometric Pericam coding sequence [gift from Dr. Atsushi Miyawaki, RIKEN, Saitama, Japan (Nagai et al., 2001)], and a poly(A) (polyadenylation) sequence was then inserted at the SmaI site to produce the transgene. Transgenic mice were produced by pronuclear injection and identified by PCR analysis of genomic DNA isolated from tail biopsies.

Immunohistochemistry. Free-floating immunocytochemistry was undertaken as reported previously (Campbell et al., 2005) using rabbit polyclonal anti-green fluorescent protein (GFP) (1:5000; A-6455; Invitrogen, San Diego, CA) to detect Pericam and a sheep polyclonal anti-GnRH (1:10,000; a gift from A. Caraty, Tours, France) antibody. This was followed by biotinylated goat anti-rabbit and anti-sheep Texas Red immunoglobulins and, finally, avidin-fluorescein. Controls included incubation of sections from nontransgenic mice and removal of the anti-GFP antiserum from the primary mixture.

Brain slice preparation and imaging. Adult ( $>60 \mathrm{~d}$ of age) male GnRHPericam mice were killed between 9:00 A.M. and 12:00 P.M. by cervical dislocation. The brains were rapidly removed and placed in ice-cold cutting artificial CSF (ACSF) solution containing the following (in $\mathrm{mm}$ ): $118 \mathrm{NaCl}, 3 \mathrm{KCl}, 0.5 \mathrm{CaCl}_{2}, 6 \mathrm{MgCl}_{2}, 5 \mathrm{HEPES}, 25 \mathrm{NaHCO}_{3}, 11$ D-glucose, $\mathrm{pH} 7.3$ when gassed with $95 \% \mathrm{O}_{2}$ and $5 \% \mathrm{CO}_{2}$. Serial coronal slices ( $150 \mu \mathrm{m}$ thick) were prepared using a vibratome, and slices were allowed to recover in a holding chamber containing oxygenated standard ACSF (in mM: $118 \mathrm{NaCl}, 3 \mathrm{KCl}, 2.5 \mathrm{CaCl}_{2}, 1.2 \mathrm{MgCl}_{2}, 5$ HEPES, 25 $\mathrm{NaHCO}_{3}, 11$ D-glucose, $\mathrm{pH} 7.3$ as above) at $30^{\circ} \mathrm{C}$ for at least $60 \mathrm{~min}$ before imaging.

For all GnRH neurons, $\left[\mathrm{Ca}^{2+}\right]_{\mathrm{i}}$ was recorded for $60 \mathrm{~min}$ to provide a baseline. For cells that were then tested with pharmacological agents, drugs were dissolved in the ACSF or in ACSF containing $<0.1 \%$ DMSO, and the cells were exposed for typically $30 \mathrm{~min}$ before returning to ACSF alone for washout. The following drugs were used: tetrodotoxin (TTX) (Alamone Labs, Jerusalem, Israel); nifedipine and caffeine (Sigma, Melbourne, Australia); 2-aminophosphonopentanoic acid (AP-5) and 2-aminoethoxydiphenylborate (2-APB) (Tocris, Bristol, UK). Zero calcium experiments were undertaken by switching to an ACSF in which the $2.5 \mathrm{~mm} \mathrm{CaCl}_{2}$ was omitted.

Slices were maintained on the stage of an Olympus (Tokyo, Japan) BX51 upright microscope equipped with a slice chamber (RC26GLP;
Warner Instruments, Hamden, CT) mounted in a heated platform (30 \pm $2^{\circ} \mathrm{C}$; PH1; Warner Instruments). Slices were held in place by weighted nylon mesh and perfused with prewarmed $\left(28-30^{\circ} \mathrm{C}\right)$ oxygenated standard ACSF solution at a rate of $1-2 \mathrm{ml} / \mathrm{min}$. The temperature of $30^{\circ} \mathrm{C}$ $\left( \pm 2^{\circ} \mathrm{C}\right)$ was chosen because it was a compromise between room temperature, which was variable, and $>32^{\circ} \mathrm{C}$, at which the slices experienced more rapid degeneration. Pericam-positive GnRH neurons were located by visual scanning of the slice at $40 \times$ magnification (LUMPlandFl; $40 \times 1$ $0.80 \mathrm{~W}$ ) under illumination at $415 \mathrm{~nm}$, and cells that exhibited classic unipolar or bipolar GnRH neuron morphology and resided in the medial septum/rostral preoptic area were selected for additional investigation. Following the protocol of Shimozono et al. (2002), but adapted for epifluorescence microscopy, we used the following image capture and analysis scheme. Excitation was alternately performed at 485 and $415 \mathrm{~nm}$ (D485/40× and D415/40×; Chroma Technology, Rockingham, VT) every 1-5 s with dichroic mirror 505DCLP (Chroma Technology), and emission filtered at $525 \mathrm{~nm}$ (HQ500LP; Chroma Technology) with the use of a Sutter Instruments Lambda DG-4 high speed filter changer (Sutter Instruments, Novato, CA). Image acquisition was performed using Metafluor software (version 6.2r2; Universal Imaging, West Chester, PA) to control and synchronize the DG-4 and liquid-cooled CCD camera (Orca-ER; Hamamatsu Instruments, Tokyo, Japan).

Analysis. A cell was defined by a region of interest (ROI) encompassing the entire cell body, and the average pixel intensity, for each ROI at each frame, was calculated by Metafluor. Background fluorescence signal was determined by copying the cell ROI to a cell-free region of the acquired image and calculating its pixel intensity, at each wavelength for each frame, in parallel with that performed for the cell ROI. The resulting data file gave, for each time point, average pixel intensities at each wavelength for each ROI. Raw data files were uploaded to a PostgreSQL relational database running on RedHat (version 9.0) Linux for data management, including linking to information about the animal, cell, and treatments, and for ease of import to subsequent analysis tools.

Ratiometric Pericam exhibits fluorescence excitation and emission in both the presence and absence of intracellular calcium. Maximal excitation of the calcium-free form is achieved at $415 \mathrm{~nm}$ and maximal excitation of the calcium-bound form is achieved at $485 \mathrm{~nm}$, with both emitting at $525 \mathrm{~nm}$ (Nagai et al., 2001). The ratio of emission generated by 485 $\mathrm{nm}$ to that generated by $415 \mathrm{~nm}$, therefore, provides an index of relative change in $\left[\mathrm{Ca}^{2+}\right]_{\mathrm{i}}$ over time. However, because Pericam bleaches differentially at the two excitation wavelengths, background-subtracted intensities were first subjected to a linear regression-based bleaching correction, after which background-subtracted ratios were calculated [per Shimozono et al. (2002)], plotted (corrected ratio vs time), and analyzed using custom software written in C++ with the QT library (Trolltech, Oslo, Norway). Data were analyzed as in Uhlen (2004) but used the Daubechies 4 discrete wavelet transform to remove Gaussian noise, detect $\left[\mathrm{Ca}^{2+}\right]_{\mathrm{i}}$ peaks, and reveal baseline trends (see Fig. $2 F, F^{\prime}$ ). The Daubechies 4 transform was chosen because it works well when applied to nonstationary data of the type gathered in these experiments, unlike the Fourier transform, which is designed to be used with stationary data. Also, the Daubechies 4 transform is not limited by knowledge of any properties of the peaks [as in statistical peak finding algorithms like PULSAR (Merriam and Wachter, 1982)]. For more information on the mathematical basis of the Daubechies 4 wavelet transform and our implementation of the analysis, see supplemental data (available at www. jneurosci.org as supplemental material). Baseline $\left[\mathrm{Ca}^{2+}\right]_{\mathrm{i}}$ was calculated across the entire recording using wavelet spectral analysis to remove signal with $>5 \%$ relative power. This method reveals a baseline trend that filters out large fluctuations and thus is not influenced by the occurrence of large transient $\left[\mathrm{Ca}^{2+}\right]_{\mathrm{i}}$ changes. Individual $\left[\mathrm{Ca}^{2+}\right]_{\mathrm{i}}$ transients were identified by the Daubechies 4 transform and considered significant if their heights were at least $10 \%$ above baseline (relative power of $>15 \%$ ). The effects of drugs on baseline $\left[\mathrm{Ca}^{2+}\right]_{\mathrm{i}}$ were calculated by comparing the average baseline during the drug test period with the average baseline in the same time period immediately preceding the treatment. The effects of drugs on $\left[\mathrm{Ca}^{2+}\right]_{\mathrm{i}}$ transient frequency were determined by counting the number of transients occurring within the drug test period and comparing this with the number of transients in the same 

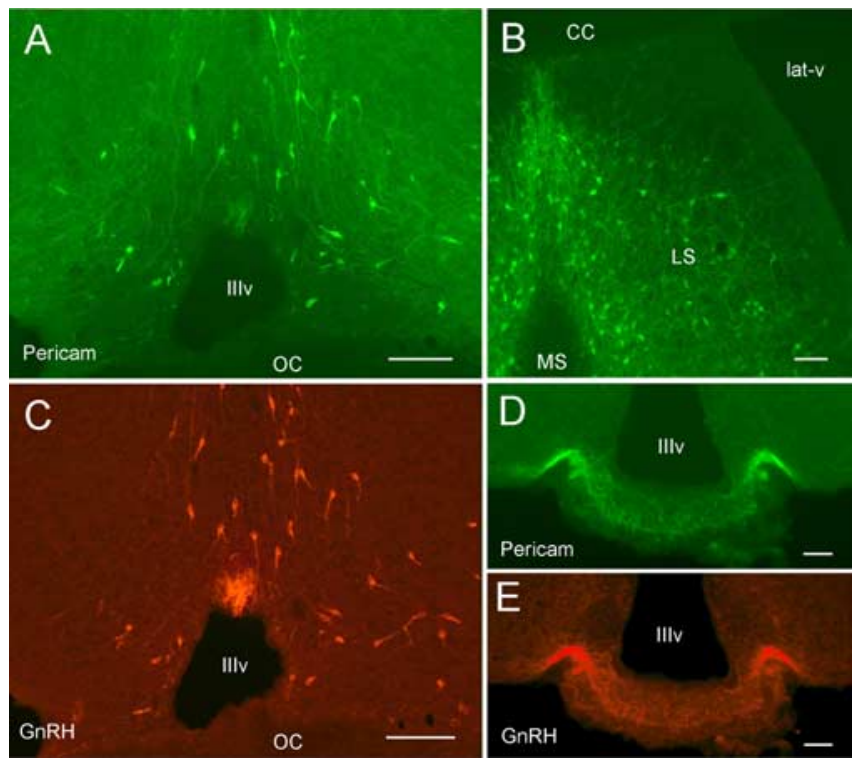

Figure 1. GnRH neurons express ratiometric Pericam in transgenic GnRH-Pericam mice. Dual-immunofluorescence labeling for ratiometric Pericam (green) and $\mathrm{GnRH}$ (red) in coronal brain sections at the level of the rostral preoptic area $(\boldsymbol{A}, \boldsymbol{C})$, septum $(\boldsymbol{B})$, and median eminence $(\boldsymbol{D}, \boldsymbol{E})$ in an adult male mouse. Note that the great majority of $\mathrm{GnRH}$ cell bodies express Pericam $(\boldsymbol{A}, \boldsymbol{C})$ and that this coexpression is also evident for the $\mathrm{GnRH}$ nerve terminals in the median eminence. Scale bars, $100 \mu \mathrm{m}$. IIIv, Third ventricle; CC, corpus callosum; lat-v, lateral ventricle; LS, lateral septum; MS, medial septum; OC, optic chiasm.

time period immediately preceding the drug treatment. Statistical analysis was performed with InStat software (GraphPad Software, San Diego, $\mathrm{CA}$ ) and used the nonparametric Wilcoxon ranked-sum two-tailed test of significance.

\section{Results}

\section{Characterization of GnRH-Pericam mice}

Expression of the Pericam transgene in GnRH neurons

To monitor $\left[\mathrm{Ca}^{2+}\right]_{\mathrm{i}}$ in adult $\mathrm{GnRH}$ neurons in situ, we developed mice expressing the ratiometric Pericam (Nagai et al., 2001) calcium indicator under the transcriptional control of the GnRH gene regulatory sequences. Five lines of GnRH-Pericam mice were created. Transgenic mice appeared normal in all respects and, as indicated by the frequency of litters and numbers of pups per litter, displayed normal levels of fertility. Immunocytochemical analysis using a green fluorescent protein antisera that recognizes ratiometric Pericam demonstrated that Pericam was expressed in populations of cells located in the septohypothalamic area with a distribution pattern typical of GnRH neurons (Fig. $1 A)$. In addition, cell bodies expressing Pericam were found in the lateral septum (Fig. $1 B$ ) and paraventricular nucleus of the thalamus ( $n=3$ adult males per line). Dual-labeling immunofluorescence for Pericam and GnRH demonstrated that, among the five lines, 75-99\% of GnRH neurons, throughout their distribution were targeted by Pericam (Fig. $1 A, C$ ), and this was also evident at the level of the GnRH nerve terminals in the median eminence (Fig. 1D,E). Pericam-expressing cells in the lateral septum and paraventricular nucleus of the thalamus did not express $\mathrm{GnRH}$ immunoreactivity. In the additional studies reported here, only mouse lines expressing Pericam in $>95 \%$ of their GnRH neurons were used.

When viewed in acute brain slices, fluorescent cells in the rostral preoptic area showed typical GnRH neuron morphology (Fig. 2A,B) and anatomical distribution, consistent with the im-
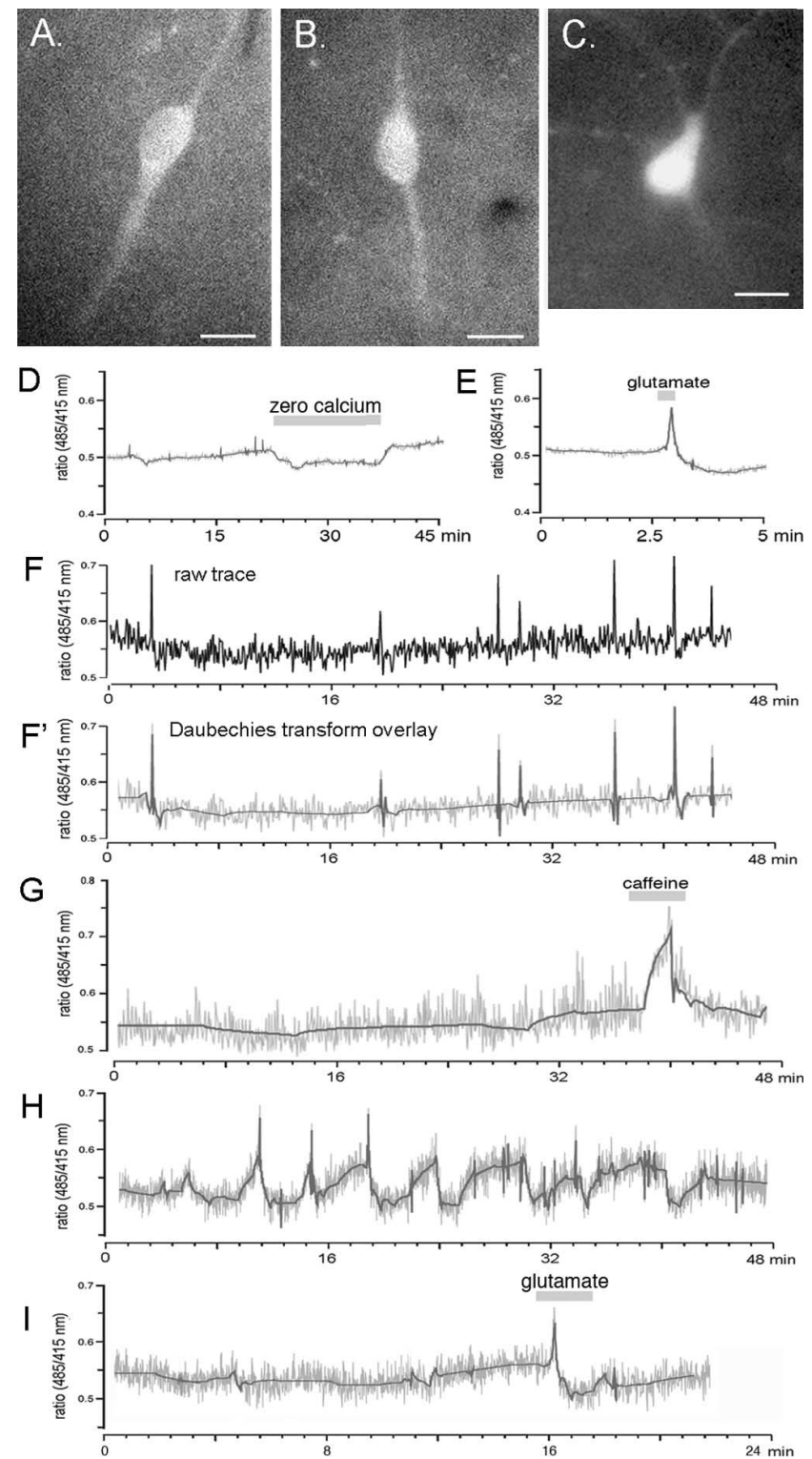

Figure 2. GnRH neurons exhibit spontaneous $\left[\mathrm{Ca}^{2+}\right]_{i}$ oscillations. $\boldsymbol{A}, \boldsymbol{B}$, Two high-power live-cell images of $\mathrm{GnRH}$ neurons expressing Pericam in an acute brain slice from GnRH-Pericam mice. C, A multipolar Pericam-expressing cell in lateral septum. Scale bars, $10 \mu \mathrm{m}$. D, Fluorescence ratio versus time recording from an adult GnRH neuron showing the effect on Pericam signal $\left(\left[\mathrm{Ca}^{2+}\right]_{\mathrm{i}}\right)$ after a switch to zero extracellular calcium. $\boldsymbol{E}$, Recording from an adult $\mathrm{GnRH}$ neuron showing the effect of glutamate $(50 \mu \mathrm{m})$ on $\left[\mathrm{Ca}^{2+}\right]_{\mathrm{i}}$. $\boldsymbol{F}$, Raw data trace depicting Pericam recorded from a GnRH neuron showing periodic $\left[\mathrm{Ca}^{2+}\right]_{\mathrm{i}}$ transients over $48 \mathrm{~min} . \boldsymbol{F}^{\prime}$, The same trace as in $\boldsymbol{F}$, but after transformation with Daubechies 4 wavelet. In this and all subsequent recordings, the dark line showing the Daubechies 4 wavelet transform is overlaid on the light gray original trace. Note that the salient features of the activity are brought out by the transformation. G, Recording from a "silent" GnRH neuron that showed no transients during the recording period. Caffeine $(30 \mathrm{~mm})$ was applied at the end of the recording period to demonstrate the ability of the cell to show a detectable increase in $\left[\mathrm{Ca}^{2+}\right]_{\mathrm{i}} \cdot \boldsymbol{H}$, Recording from a rare GnRH neuron showing the slow pattern of $\left[\mathrm{Ca}^{2+}\right]_{i}$ oscillations. $I$, Trace from a Pericamexpressing non-GnRH lateral septal cell showing the absence of $\left[\mathrm{Ca}^{2+}\right]_{\mathrm{i}}$ transients. Despite the lack of transients, the cell responded with a large transient increase in $\left[\mathrm{Ca}^{2+}\right]_{i}$ after challenge with glutamate $(50 \mu \mathrm{M})$, indicating that the Pericam functioned normally and the cell was alive during this recording period.

munocytochemical findings, whereas fluorescent cells located in the lateral septum and thalamus exhibited a different, typically multipolar, morphology (Fig. 2C). The number of fluorescing $\mathrm{GnRH}$ neurons that could be viewed in living slices was approx- 

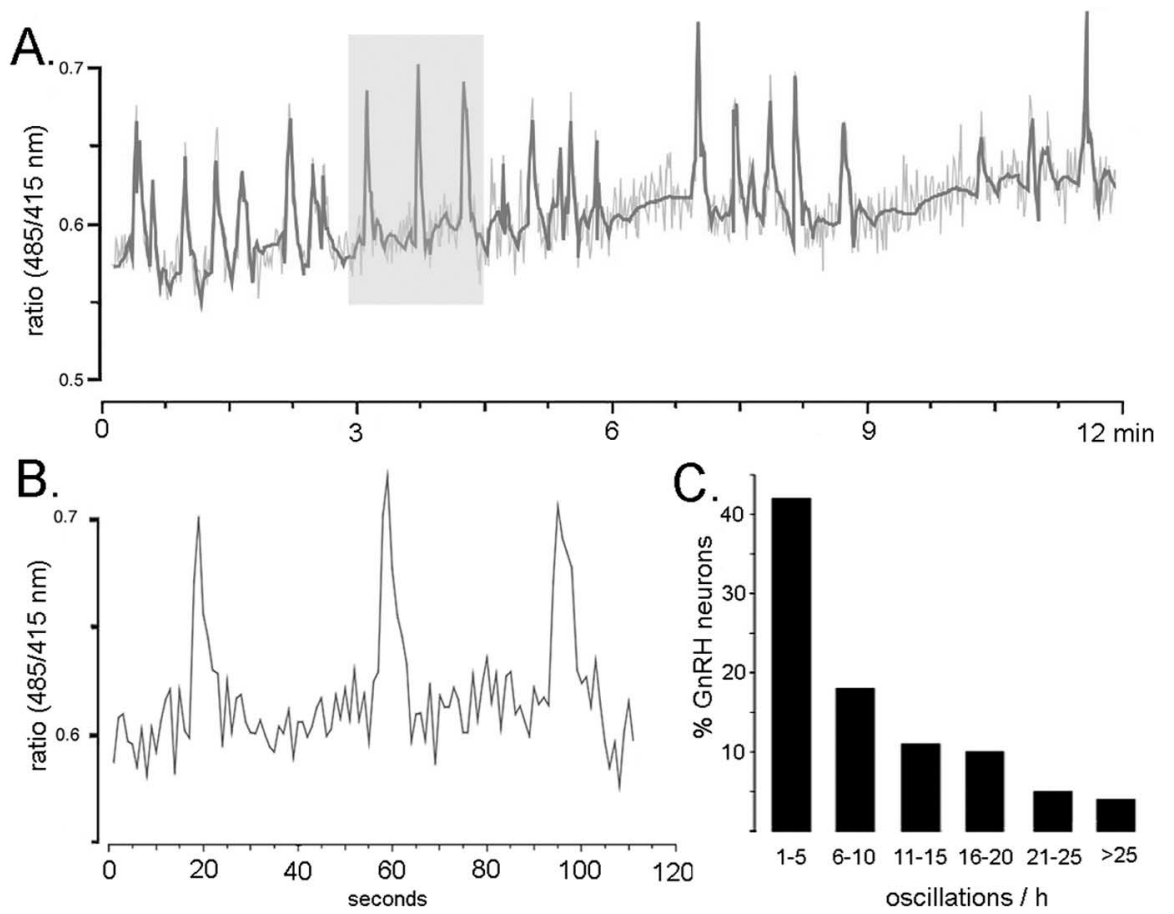

Figure 3. $\left[\mathrm{Ca}^{2+}\right]_{\mathrm{i}}$ transient dynamics and frequency distribution within the $\mathrm{GnRH}$ neuron population exhibiting fast type $\left[\mathrm{Ca}^{2+}\right]_{i}$ transients. $A$, Example of a $\mathrm{GnRH}$ neuron exhibiting calcium transients that was recorded at a sampling interval of $500 \mathrm{~ms}$ over $12 \mathrm{~min}$. Shading indicates the area shown at increased magnification in $\boldsymbol{B}$. $\boldsymbol{B}$, High-resolution view of three $\left[\mathrm{Ca}^{2+}\right]_{i}$ oscillations, demonstrating the relatively rapid release period, followed by reuptake. $C$, Bar graph showing the frequency distribution of $\left[\mathrm{Ca}^{2+}\right]_{\mathrm{i}}$ transient frequencies within the GnRH neuron population showing fast-type transients. The mean frequency, calculated across all cells represented in the histograms, is $7.2 \pm 1.3$ transients $/ \mathrm{h}$.

imately fivefold lower than the number of cells identified with green fluorescent protein immunocytochemistry in fixed tissue. This is likely to be attributable to the low levels of detectable endogenous fluorescence in vivo and the relatively poor optical clarity of the thick living slices. The two lines of GnRH-Pericam mice exhibiting the highest numbers of fluorescent GnRHPericam cells $(>95 \%)$ were used for the experiments described here. No differences in Pericam expression were detected between heterozygous and homozygous male mice from these two lines.

\section{Ability of Pericam to report $\left[\mathrm{Ca}^{2+}\right]_{i}$ milieu in}

GnRH-Pericam neurons

Initial experiments were performed to ensure that the Pericam indicator was able to report $\left[\mathrm{Ca}^{2+}\right]_{\mathrm{i}}$ levels within $\mathrm{GnRH}$ neurons. GnRH-Pericam neurons were recorded to establish a baseline, and then treated with agents that have established effects on $\left[\mathrm{Ca}^{2+}\right]_{\mathrm{i}}$. Glutamate $(50 \mu \mathrm{M})$ (Fig. $2 \mathrm{E}$ ) or caffeine $(30 \mathrm{~mm})$ (Fig. $2 G$ ) caused a brief, large increase in $\left[\mathrm{Ca}^{2+}\right]_{i}$, whereas removal of extracellular calcium $\left(\left[\mathrm{Ca}^{2+}\right]_{\mathrm{e}}\right)$ resulted either in no change or a decrease in $\left[\mathrm{Ca}^{2+}\right]_{i}$ that was sustained until cells were switched back to normal (2.5 mM) $\left[\mathrm{Ca}^{2+}\right]_{\mathrm{e}}$ (Fig. 2D).

\section{Adult GnRH neurons exhibit $\left[\mathrm{Ca}^{2+}\right]_{\mathrm{i}}$ transients}

Recordings from $135 \mathrm{GnRH}$ neurons revealed the existence of three distinct populations of $\mathrm{GnRH}$ neurons exhibiting different $\left[\mathrm{Ca}^{2+}\right]_{i}$ profiles. The pattern of $\left[\mathrm{Ca}^{2+}\right]_{i}$ changes did not have any relationship to the anatomical location of the GnRH neuron within the basal forebrain. In the most numerous population, $67 \%$ of $\mathrm{GnRH}$ neurons (90 of 135) exhibited spontaneous fast fluctuations in $\left[\mathrm{Ca}^{2+}\right]_{\mathrm{i}}$ at irregular intervals (Figs. $2 F, F^{\prime}, 3 A$ ) for as long as the cell was recorded, typically $1-2 \mathrm{~h}$, but up to $3 \mathrm{~h}$ on occasion. The mean frequency of these transients was $7.2 \pm 1.3$ transients $/ \mathrm{h}$, but cells exhibited a wide range of frequencies (1-55 peaks/h) (Fig. 3C). In the second population, 29\% of GnRH neurons exhibited a stable $\left[\mathrm{Ca}^{2+}\right]_{\mathrm{i}}$ with no transients over the $60 \mathrm{~min}$ recording period (Fig. $2 G)$. The final small population representing $4 \%$ of $\mathrm{GnRH}$ neurons (5 of 135) displayed a pattern of slow baseline $\left[\mathrm{Ca}^{2+}\right]_{\mathrm{i}}$ transients with each event lasting an average of $3.5 \pm 1.3 \mathrm{~min}$ ( $n=17$ transients) (Fig. $2 H$ ). Interestingly, this type of $\left[\mathrm{Ca}^{2+}\right]_{\mathrm{i}}$ fluctuation was often associated with a fast transient at the apex of the slow wave (Fig. $2 \mathrm{H}$ ). The infrequency of $\mathrm{GnRH}$ neurons exhibiting these slow transients precluded detailed investigation, and this type of $\left[\mathrm{Ca}^{2+}\right]_{\mathrm{i}}$ fluctuation is not considered in any of our additional analysis.

The lateral septal cells expressing Pericam are easily differentiated from the GnRH neurons based on cell morphology (Fig. 2C) and anatomical location (Fig. $1 B)$. To examine whether these cells might also exhibit spontaneous $\left[\mathrm{Ca}^{2+}\right]_{\mathrm{i}}$ transients, we examined 10 lateral septal cells for $>1 \mathrm{~h}$. None of these cells exhibited any fluctuations in $\left[\mathrm{Ca}^{2+}\right]_{\mathrm{i}}$, despite their vitality as evidenced by an acute influx of $\mathrm{Ca}^{2+}$ in response to glutamate $(50 \mu \mathrm{M})$ at the end of the recording session (Fig. $2 I$ ).

To analyze the dynamics of individual transients, eight $\mathrm{GnRH}$ neurons were recorded at a $500 \mathrm{~ms}$ sampling interval (Fig. $3 \mathrm{~A}, B$ ). This demonstrated that each transient lasted an average of $13.7 \pm$ $4.4 \mathrm{~s}(n=63$ peaks $)$ with a relatively rapid $3-4 \mathrm{~s}$ release period followed by a decay of $8-10 \mathrm{~s}$ (Fig. $3 B$ ). The reuptake period lasted on average three to four times longer than the release period, and there was no plateau period.

\section{$\left[\mathrm{Ca}^{2+}\right]_{\mathrm{i}}$ transients in GnRH neurons depend on release from intracellular stores}

To investigate the mechanisms underlying the spontaneous $\left[\mathrm{Ca}^{2+}\right]_{\mathrm{i}}$ transients observed in GnRH neurons, we used pharmacological manipulations to perturb potential $\mathrm{Ca}^{2+}$ influx mechanisms. The relatively slow dynamics of the $\left[\mathrm{Ca}^{2+}\right]_{\mathrm{i}}$ transients observed in GnRH neurons suggested that internal store mechanisms were involved. As such, we began by evaluating the effects of the $\mathrm{IP}_{3}$ receptor $\left(\mathrm{IP}_{3} \mathrm{R}\right)$ blocker 2-APB (Peppiatt et al., 2003) on transients. 2-APB $(50-100 \mu \mathrm{M})$ was found to have a potent suppressive action on transients. In 11 of $12 \mathrm{GnRH}$ neurons, 2-APB completely abolished $\left[\mathrm{Ca}^{2+}\right]_{\mathrm{i}}$ influx events (Fig. $\left.4 A, B\right)$ and, overall, resulted in a $99 \%(p=0.001)$ reduction in $\left[\mathrm{Ca}^{2+}\right]_{\mathrm{i}}$ transient frequency (Fig. $4 C$ ). In all treated cells, 2-APB was also observed to induce a significant drop in baseline $\left[\mathrm{Ca}^{2+}\right]_{\mathrm{i}}(p<$ 0.01 ) (Fig. $4 A, B)$. Vehicle control (0.1\% DMSO; $n=5)$ had no significant effect on baseline $\left[\mathrm{Ca}^{2+}\right]_{\mathrm{i}}$ or transients.

Because 2-APB has been shown to block store-operated plasma membrane $\mathrm{Ca}^{2+}$ channels (Iwasaki et al., 2001), we further examined the role for release of calcium from intracellular stores by using caffeine at low concentrations (5-10 $\mu \mathrm{M})$ known to block $\mathrm{IP}_{3} \mathrm{R}$ channels selectively (Berridge, 1991). Low caffeine was also found to reduce the frequency of fast transients (Fig. 

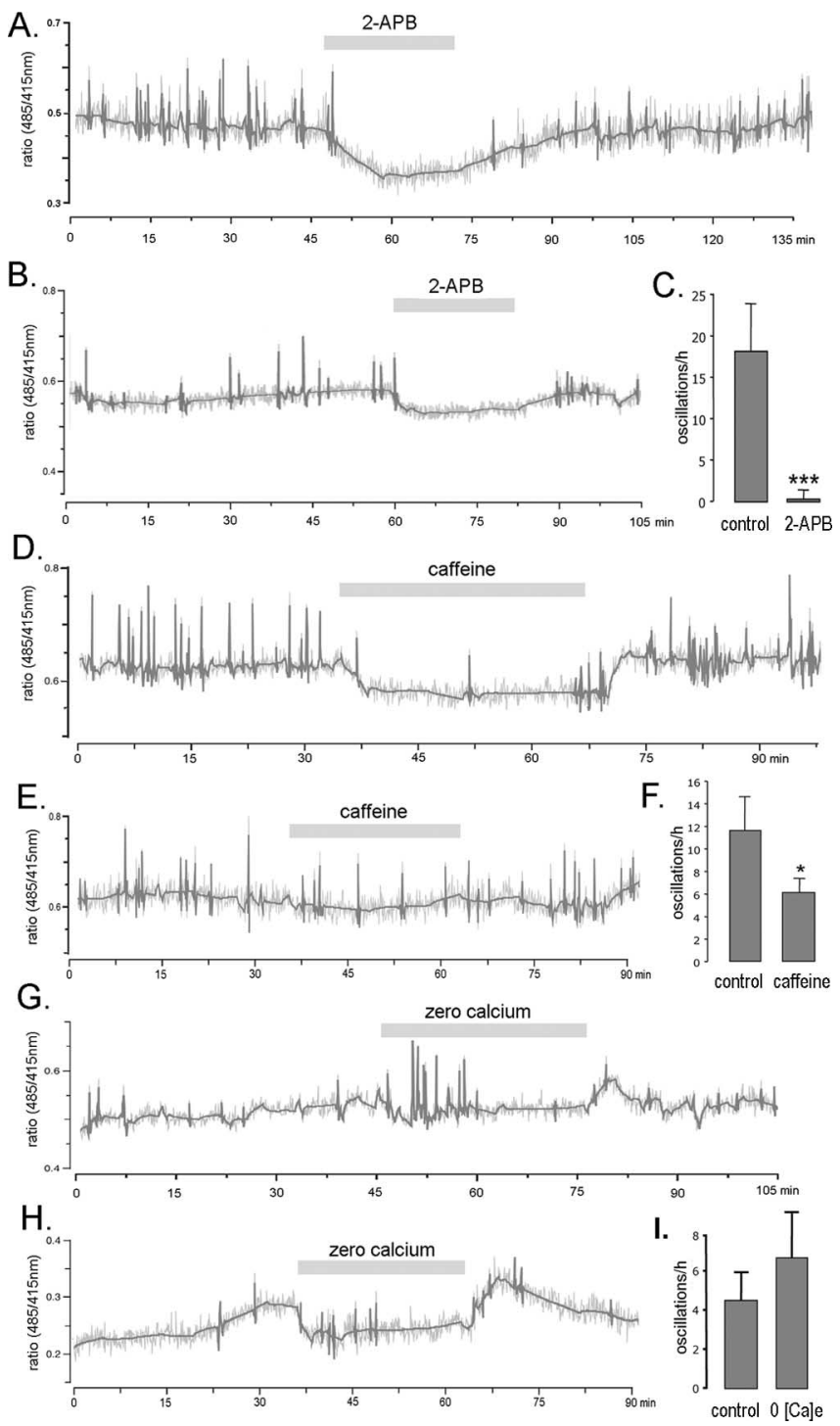

Figure 4. An $I P_{3} R$-dependent store release mechanism is required for spontaneous calcium transients in GnRH neurons. $\boldsymbol{A}, \boldsymbol{B}$, Two representative examples of $\mathrm{GnRH}$ neurons showing $\left[\mathrm{Ca}^{2+}\right]_{\mathrm{i}}$ transients that were abolished by treatment with $75 \mu \mathrm{M} 2$ 2-APB. C, Bar graph showing the mean (+SEM) oscillation frequency in control and 2-APB-treated cells $\left({ }^{* * *} p<0.001\right)$. $\boldsymbol{D}$, $\boldsymbol{E}$, Two examples of $\mathrm{GnRH}$ neurons showing $\left[\mathrm{Ca}^{2+}\right]_{\mathrm{i}}$ transients that were diminished by treatment with $10 \mu$ m caffeine. $F$, Bar graph showing the mean (+SEM) oscillation frequency in control and caffeine-treated cells ( $\left.{ }^{*} p<0.05\right)$. $\boldsymbol{G}, \boldsymbol{H}$, Two examples of GnRH neurons that exhibited variable changes in $\left[\mathrm{Ca}^{2+}\right]_{\mathrm{i}}$ oscillation behavior in response to treatment with zero extracellular calcium. I, Bar graph showing the mean ( + SEM) oscillation frequency in control and zero calcium-treated GnRH neurons.

$4 D, E)$, but was not as potent as 2 -APB and resulted in a mean reduction in transient frequency of $45 \%(p<0.05 ; n=8)$ (Fig. $4 F)$. Incubation in low concentration caffeine also elicited a significant, $\sim 4 \%$, reduction in baseline $\left[\mathrm{Ca}^{2+}\right]_{\mathrm{i}}(p<0.01 ; n=8)$ (Fig. $4 D$ ). In contrast, high-dose $30 \mathrm{~mm}$ caffeine was found to exert a potent and rapid increase in $\left[\mathrm{Ca}^{2+}\right]_{\mathrm{i}}$ in all $\mathrm{GnRH}$ neurons tested ( $n=40$ ) (Fig. $2 G$ ), suggesting the expression of ryanodine receptors (RyRs) in these cells. Treatment with high concentration $(50 \mu \mathrm{M})$ ryanodine, however, was ineffective at diminishing spontaneous $\left[\mathrm{Ca}^{2+}\right]_{\mathrm{i}}$ transients in $\mathrm{GnRH}$ neurons $(n=3)$ (data not shown) confirming the role for $\mathrm{IP}_{3} \mathrm{R}$-dependent store release.

To evaluate further the potential role of internal versus external $\mathrm{Ca}^{2+}$ sources in generating $\left[\mathrm{Ca}^{2+}\right]_{\mathrm{i}}$ transients in $\mathrm{GnRH}$ neurons, slices were perfused in $0 \mathrm{~mm}$ external $\left[\mathrm{Ca}^{2+}\right]\left(\left[\mathrm{Ca}^{2+}\right]_{\mathrm{e}}\right)$.
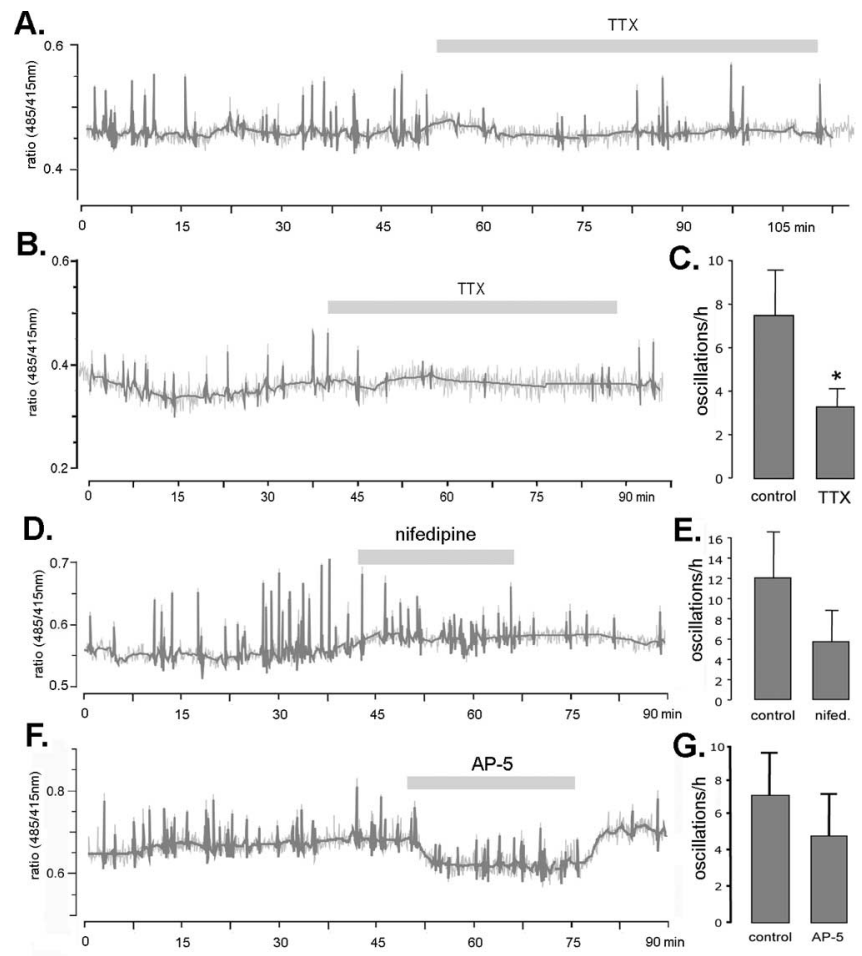

Figure 5. Inputs to $\mathrm{GnRH}$ neurons modulate $\left[\mathrm{Ca}^{2+}\right]_{\mathrm{i}}$ transient frequency. $\boldsymbol{A}, \boldsymbol{B}$, Two representative examples of $\mathrm{GnRH}$ neurons showing $\left[\mathrm{Ca}^{2+}\right]_{i}$ oscillations that were reduced in frequency, but not abolished, in the presence of $0.5 \mu \mathrm{m}$ TTX. C, Bar graph showing the mean (+SEM) oscillation frequency in control and TTX-treated cells $\left({ }^{*} p<0.05\right)$. D, Recording showing the effects of $25 \mu \mathrm{m}$ nifedipine on an oscillating $\mathrm{GnRH}$ neuron. $\boldsymbol{E}$, Bar graph showing the mean (+SEM) transient frequency in control and nifedipine-treated cells. $\boldsymbol{F}$, GnRH neuron

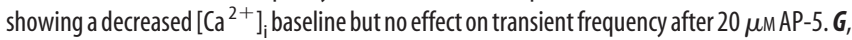
Bar graph showing the mean (+SEM) transient frequency in control and AP-5-treated cells.

Zero $\left[\mathrm{Ca}^{2+}\right]_{\mathrm{e}}$ had variable effects on $\mathrm{GnRH}$ neurons but, overall, did not result in a significant change in transient frequency with 11 of $12 \mathrm{GnRH}$ neurons continuing to exhibit $\left[\mathrm{Ca}^{2+}\right]_{\mathrm{i}}$ transients in $0 \mathrm{~mm}\left[\mathrm{Ca}^{2+}\right]_{\mathrm{e}}$ (Fig. 4G-I). Finally, we treated with 2-APB in 0 $\left[\mathrm{Ca}^{2+}\right]_{\mathrm{e}}$ and found that the effects of 2 -APB without extracellular calcium were identical with 2 -APB in the presence of calcium $(n=3)$ (data not shown). Together, our results confirm that transient elevations in $\left[\mathrm{Ca}^{2+}\right]_{\mathrm{i}}$ were dependent on $\mathrm{IP}_{3} \mathrm{Rs}$, and not driven directly by influx of extracellular calcium.

\section{Electrical activity modulates the frequency of $\left[\mathrm{Ca}^{2+}\right]_{i}$ transients in GnRH neurons}

Although the observations above indicated that internal mechanisms involving $\mathrm{IP}_{3} \mathrm{Rs}$ were critical in enabling $\left[\mathrm{Ca}^{2+}\right]_{\mathrm{i}}$ transients to occur in GnRH neurons, it remained to be established whether the oscillation mechanism was an inherent property of the cells or driven by external inputs. To explore this, we evaluated the ability of cells to exhibit transients in the presence of TTX.

In the presence of $0.5 \mu \mathrm{M}$ TTX, voltage-dependent sodium channels are blocked, effectively isolating the recorded $\mathrm{GnRH}$ neurons from action potential-dependent inputs (Sim et al., 2001). Although TTX was found to decrease the frequency of $\left[\mathrm{Ca}^{2+}\right]_{\mathrm{i}}$ transients by $\sim 50 \%(p<0.05),\left[\mathrm{Ca}^{2+}\right]_{\mathrm{i}}$ transients were never completely abolished in any of the $12 \mathrm{GnRH}$ neurons examined (Fig. 5A-C).

Depolarization-induced calcium influx occurs through L-type VGCC in electrically excitable cells, including GT1 cells and embryonic GnRH neurons (Krsmanovic et al., 1992; Charles 
and Hales, 1995; Terasawa et al., 1999; Moore and Wray, 2000). Despite a trend toward a decreased transient frequency $(n=9$; $p=0.1$ ), there was no significant effect of the L-type VGCC blocker nifedipine on $\left[\mathrm{Ca}^{2+}\right]_{\mathrm{i}}$ transient occurrence (Fig. $5 \mathrm{D}, E$ ). Nifedipine was, however, found to increase baseline $\left[\mathrm{Ca}^{2+}\right]_{\mathrm{i}}$ significantly $(n=9 ; p<0.01)$. The majority of $\mathrm{GnRH}$ neurons have been shown to express functional NMDA receptors (KuehlKovarik et al., 2002; Shimshek et al., 2005). The NMDA receptor antagonist AP-5 $(20 \mu \mathrm{M})$ had no effect $(n=7 ; p>0.05)$ on $\left[\mathrm{Ca}^{2+}\right]_{\mathrm{i}}$ transient frequency (Fig. $5 F, G$ ) but significantly decreased baseline $\left[\mathrm{Ca}^{2+}\right]_{\mathrm{i}}(n=7 ; p<0.05)$. Together, these observations indicate that $\mathrm{GnRH}$ neurons possess both L-type VGCC and NMDA receptor-mediated influx of calcium across the plasma membrane, but that they do not contribute to $\left[\mathrm{Ca}^{2+}\right]_{\mathrm{i}}$ transients observed in these cells.

\section{Discussion}

We report here a transgenic strategy for investigating $\left[\mathrm{Ca}^{2+}\right]_{\mathrm{i}}$ dynamics in specific neuronal cell populations in situ and use this to show that the majority of adult GnRH neurons exhibit spontaneous, $10-15 \mathrm{~s}$ duration $\left[\mathrm{Ca}^{2+}\right]_{\mathrm{i}}$ fluctuations. These transients were found to depend on intracellular store release mechanisms involving $\mathrm{IP}_{3} \mathrm{Rs}$ and, although modulated by inputs, were an inherent property of $\mathrm{GnRH}$ neurons. Such spontaneous $\left[\mathrm{Ca}^{2+}\right]_{\mathrm{i}}$ oscillations have not been identified previously in adult neurons and we did not observe $\left[\mathrm{Ca}^{2+}\right]_{\mathrm{i}}$ oscillations in lateral septal neurons in GnRH-Pericam mice. Smooth muscle cells in the lung (Perez and Sanderson, 2005a,b), have been identified to exhibit spontaneous $\left[\mathrm{Ca}^{2+}\right]_{\mathrm{i}}$ oscillations, and, within the brain, astrocytes exhibit spontaneous oscillations in $\left[\mathrm{Ca}^{2+}\right]_{\mathrm{i}}$ (Parri et al., 2001; Aguado et al., 2002; Nett et al., 2002; Parri and Crunelli, 2003). The present results demonstrate a novel $\left[\mathrm{Ca}^{2+}\right]_{i}$ profile in mature neurons and indicate the usefulness of transgenic targeting of genetically encodable calcium indicator molecules in revealing the properties of specific neuronal phenotypes.

The scattered topography of the GnRH neuron cell bodies in the mammalian brain has prevented definitive cellular and molecular investigations of their properties. The recent use of $\mathrm{GnRH}$ promoter transgenics to drive the expression of molecules such as $\beta$-galactosidase (Skynner et al., 1999), green fluorescent protein (Spergel et al., 1999; Suter et al., 2000; Fujioka et al., 2003; Han et al., 2004), Cre recombinase (Shimshek et al., 2002; Yoon et al., 2005; Wintermantel et al., 2006), and lectin (Boehm et al., 2005) in $\mathrm{GnRH}$ neurons has provided a new avenue for the detailed investigation of this neuronal phenotype. Using this same strategy, we report here the production of a mouse line in which ratiometric Pericam is efficiently targeted to the great majority of GnRH neurons. We note that Pericam was also expressed by populations of cells in the lateral septum and thalamus. The targeting of transgene expression to the lateral septum in $\mathrm{GnRH}$ transgenics is common (Herbison, 2006) and thought to result from the absence of repressor elements in the GnRH transgene that are responsible for switching off GnRH gene expression in lateral septal cells during the second postnatal week (Skynner et al., 1999). For unknown reasons, previous investigators have had little success in generating useful calcium-sensing transgenic mouse lines, including GnRH promoter-driven mice (Hasan et al., 2004). We generated five founder lines using our standard approach (Pape et al., 1999; Skynner et al., 1999). Two of these showed Pericam in $>95 \%$ of GnRH neurons and were of sufficient fluorescence intensity to permit real-time $\left[\mathrm{Ca}^{2+}\right]_{\mathrm{i}}$ monitoring in acute brain slices.

A variety of genetically encodable calcium indicator molecules are now available including Cameleons, GCaMPs, Camgaroos, and Pericam variants (Tsien, 2003; Miyawaki, 2005). We chose to use ratiometric Pericam in these studies for several reasons. First, at the time this project was initiated, there had been very little progress in generating useful transgenic mice with Cameleons and Camgaroos. Very recent studies have, however, been at least partially successful with Camgaroo 2 (Hasan et al., 2004) and also GCaMP (Diez-Garcia et al., 2005). Second, the Pericams have significant advantages to Cameleons and Camgaroos in exhibiting higher affinity for $\mathrm{Ca}^{2+}$ and greater dynamic range (Nagai et al., 2001). Third, and most importantly, the use of ratiometric Pericam minimizes potential artifacts caused by bleaching, which are critical when individual cells are to be visualized for long periods. The caveats of the ratiometric Pericam indicator are that it is unlikely to be able to follow individual action potentials in a spike train (Pologruto et al., 2004) and that it exhibits modest $\mathrm{pH}$ sensitivity (Nagai et al., 2001). Finally, as with all calcium-sensing variants of this type, it remains possible that the Pericam may in some way interfere with the normal calcium-dependent biochemical processes in the GnRH neuron. If it exists, any such interaction is not critical as GnRH-Pericam mouse lines breed normally and any significant perturbation of the GnRH neuron would result in subfertility.

We find that approximately two-thirds of mature GnRH neurons exhibit spontaneous $\left[\mathrm{Ca}^{2+}\right]_{i}$ transients and present evidence that these events are generated by inositol-1,4,5trisphosphate receptor $\left(\mathrm{Ins}_{3} \mathrm{R}\right)$-dependent calcium release from internal stores. First, transients were blocked completely by the Ins $\mathrm{P}_{3} \mathrm{R}$ antagonist 2-APB and partially by low concentrations of caffeine. It is likely that caffeine treatment was less effective than $2-\mathrm{APB}$ as a result of its opposing, concentration-dependent, effects on $\mathrm{InsP}_{3} \mathrm{R}$ and RyR (Ehrlich et al., 1994). Single GnRH neuron microarray experiments have indicated that both $\operatorname{Ins}_{3} \mathrm{R}$ and RyR transcripts are expressed by adult male GnRH neurons (M. G. Todman and A. E. Herbison, unpublished observations). Second, $\left[\mathrm{Ca}^{2+}\right]_{i}$ transients remained in the presence of $0 \mathrm{~mm}$ $\left[\mathrm{Ca}^{2+}\right]_{\mathrm{e}}$. This demonstrates that extracellular calcium entry is not required for transients to exist in $\mathrm{GnRH}$ neurons and also discounts the possibility that the suppression by 2 -APB resulted from blockade of transient receptor potential channels (Iwasaki et al., 2001). Third, and in additional support of the redundancy of extracellular calcium in this mechanism, blockade of both L-type VGCC and NMDA receptors had no significant effect on $\left[\mathrm{Ca}^{2+}\right]_{\mathrm{i}}$ transients. Together with evidence for the multisecond duration of each transient, these observations provide strong support for the concept that $\operatorname{Ins}_{3} \mathrm{P}_{3}$ are critically involved in the store-dependent generation of spontaneous $\left[\mathrm{Ca}^{2+}\right]_{\mathrm{i}}$ transients in $\mathrm{GnRH}$ neurons. Interestingly, this mechanism is completely different from that underlying $\left[\mathrm{Ca}^{2+}\right]_{\mathrm{i}}$ transients in embryonic or immortalized GnRH neurons in which entry of extracellular calcium through VGCC is required (Charles and Hales, 1995; Spergel et al., 1995; Terasawa et al., 1999; Van Goor et al., 1999a,b).

Calcium transients persisted in the presence of the voltagedependent sodium channel blocker TTX. Because TTX blocks all action potential-mediated transmission to GnRH neurons in this brain slice preparation (Sim et al., 2001), this suggests that the mechanism driving $\left[\mathrm{Ca}^{2+}\right]_{\mathrm{i}}$ transients in GnRH neurons is autonomous and does not require action potential generation. One of the key unanswered questions in reproductive neurobiology is that of how GnRH neurons generate an episodic pattern of GnRH secretion (Moenter et al., 2003; Herbison, 2006). Early studies using the immortalized GnRH-secreting GT1 cell lines 
demonstrated that pulsatile $\mathrm{GnRH}$ secretion was possible in cultures that contained only GT1 cells, thereby suggesting that $\mathrm{GnRH}$ neurons had inherent pulse-generating properties (Krsmanovic et al., 1992; Martinez de la Escalera et al., 1992; Wetsel et al., 1992). Subsequent studies using cultured embryonic olfactory placodes containing GnRH and other cells also demonstrated pulsatile GnRH release (Terasawa et al., 1999; Moore et al., 2002). We now provide here evidence that mature $\mathrm{GnRH}$ neurons possess a spontaneous episode generator. This is a key finding supporting the concept that intrinsic oscillatory mechanisms exist within GnRH neurons. Although it is clear that a one-to-one correspondence does not exist between cytoplasmic $\left[\mathrm{Ca}^{2+}\right]_{\mathrm{i}}$ transients (mean interval of $8 \mathrm{~min}$ ) and the pulses of $\mathrm{GnRH}$ nerve terminal secretion (mean interval of $>30 \mathrm{~min}$ ), the critical point is that adult GnRH neurons possess an intrinsic oscillatory mechanism. An autonomous oscillator such as this would obviate the need to initiate each episodic event de novo via extrinsic stimulation, and, therefore, fewer levels of control would be required to ensure rhythmic behavior. However, the relationship between spontaneous $\left[\mathrm{Ca}^{2+}\right]_{\mathrm{i}}$ transients and episodic GnRH neuron secretion remains to be ascertained.

We found that $\left[\mathrm{Ca}^{2+}\right]_{\mathrm{i}}$ transient frequency was reduced in the presence of TTX indicating that inputs to GnRH neurons are likely to play a role in modulating the frequency of transients. The mechanisms underlying this regulation are not clear. Biologically based mathematical modeling has demonstrated that $\left[\mathrm{Ca}^{2+}\right]_{\mathrm{i}}$ itself can regulate transient frequency by influencing the open probability of the $\mathrm{InsP}_{3} \mathrm{R}$ (Mak et al., 1998; Foskett and Mak, 2004), a mechanism that can generate self-sustaining oscillations. Moreover, the extracellular pool appears to be the key source of this "regulatory" calcium that modulates the $\left[\mathrm{Ca}^{2+}\right]_{\mathrm{i}}$ needed for oscillations (Sneyd et al., 2004). However, it is clear from our studies that the baseline $\left[\mathrm{Ca}^{2+}\right]_{\mathrm{i}}$ levels in $\mathrm{GnRH}$ neurons are not critical in establishing the transient frequency. For example, the NMDA receptor antagonist AP-5 induced a consistent drop in baseline $\left[\mathrm{Ca}^{2+}\right]_{\mathrm{i}}$ without having any effect on transient frequency. Equally, the fall in transient frequency during TTX treatment was not associated with any change in baseline $\left[\mathrm{Ca}^{2+}\right]_{\mathrm{i}}$. As such, it seems more likely that specific signaling pathways not involving calcium directly, are being activated by GnRH neuronal afferents to modulate $\mathrm{Ins}_{3}$-mediated calcium release in $\mathrm{GnRH}$ neurons. As one possibility, there is a growing appreciation that synaptically activated metabotropic receptors can have an impact on the dynamics of store-mediated calcium release (Ross et al., 2005).

In summary, we show here that ratiometric Pericam provides an ideal genetically encodable indicator for assessing $\left[\mathrm{Ca}^{2+}\right]_{\mathrm{i}}$ on a $\geq 1 \mathrm{~s}$ temporal resolution in individual neurons in situ. Using this approach we have uncovered a remarkable ability of adult $\mathrm{GnRH}$ neurons to exhibit intrinsic $\left[\mathrm{Ca}^{2+}\right]_{\mathrm{i}}$ transients that are based on an Ins $\mathrm{P}_{3} \mathrm{R}$-dependent mechanism modulated by extrinsic afferent input. This provides the first evidence of spontaneous $\left[\mathrm{Ca}^{2+}\right]_{i}$ fluctuations in a mature neuron and demonstrates that adult $\mathrm{GnRH}$ neurons possess an innate oscillator.

\section{References}

Aguado F, Espinosa-Parrilla JF, Carmona MA, Soriano E (2002) Neuronal activity regulates correlated network properties of spontaneous calcium transients in astrocytes in situ. J Neurosci 22:9430-9444.

Ben-Ari Y, Spitzer NC (2004) Nature and nurture in brain development. Trends Neurosci 27:361.

Berridge MJ (1991) Caffeine inhibits inositol-trisphosphate-induced membrane potential oscillations in Xenopus oocytes. Proc Biol Sci 244:57-62.
Berridge MJ, Bootman MD, Roderick HL (2003) Calcium signalling: dy namics, homeostasis and remodelling. Nat Rev Mol Cell Biol 4:517-529.

Boehm U, Zou Z, Buck LB (2005) Feedback loops link odor and pheromone signaling with reproduction. Cell 123:683-695.

Campbell RE, Han SK, Herbison AE (2005) Biocytin filling of adult gonadotropin-releasing hormone neurons in situ reveals extensive, spiny, dendritic processes. Endocrinology 146:1163-1169.

Charles AC, Hales TG (1995) Mechanisms of spontaneous calcium oscillations and action potentials in immortalized hypothalamic (GT1-7) neurons. J Neurophysiol 73:56-64.

Diez-Garcia J, Matsushita S, Mutoh H, Nakai J, Ohkura M, Yokoyama J, Dimitrov D, Knopfel T (2005) Activation of cerebellar parallel fibers monitored in transgenic mice expressing a fluorescent $\mathrm{Ca}^{2+}$ indicator protein. Eur J Neurosci 22:627-635.

Ehrlich BE, Kaftan E, Bezprozvannaya S, Bezprozvanny I (1994) The pharmacology of intracellular $\mathrm{Ca}^{2+}$-release channels. Trends Pharmacol Sci 15:145-149.

Foskett JK, Mak DO (2004) Novel model of calcium and inositol 1,4,5trisphosphate regulation of InsP3 receptor channel gating in native endoplasmic reticulum. Biol Res 37:513-519.

Fujioka H, Suzuki M, Yamanouchi K, Ohta A, Nagashima H, Kato M, Nishihara M (2003) Generation of transgenic rats expressing enhanced green fluorescent protein in gonadotropin-releasing hormone neurons. J Reprod Dev 49:523-529.

Han SK, Todman MG, Herbison AE (2004) Endogenous GABA release inhibits the firing of adult gonadotropin-releasing hormone neurons. Endocrinology 145:495-499.

Hasan MT, Friedrich RW, Euler T, Larkum ME, Giese G, Both M, Duebel J, Waters J, Bujard H, Griesbeck O, Tsien RY, Nagai T, Miyawaki A, Denk W (2004) Functional fluorescent $\mathrm{Ca}^{2+}$ indicator proteins in transgenic mice under TET control. PLoS Biol 2:e163.

Herbison AE (2006) Physiology of the GnRH neuronal network. In: Knobil and Neill's physiology of reproduction, Ed 3 (Neill JD, ed), pp 1415-1482. San Diego: Academic.

Iwasaki H, Mori Y, Hara Y, Uchida K, Zhou H, Mikoshiba K (2001) 2-Aminoethoxydiphenyl borate (2-APB) inhibits capacitative calcium entry independently of the function of inositol 1,4,5-trisphosphate receptors. Receptors Channels 7:429-439.

Jaffe DB, Johnston D, Lasser-Ross N, Lisman JE, Miyakawa H, Ross WN (1992) The spread of $\mathrm{Na}^{+}$spikes determines the pattern of dendritic $\mathrm{Ca}^{2+}$ entry into hippocampal neurons. Nature 357:244-246.

Koester HJ, Sakmann B (1998) Calcium dynamics in single spines during coincident pre- and postsynaptic activity depend on relative timing of back-propagating action potentials and subthreshold excitatory postsynaptic potentials. Proc Natl Acad Sci USA 95:9596-9601.

Kovalchuk Y, Eilers J, Lisman J, Konnerth A (2000) NMDA receptormediated subthreshold $\mathrm{Ca}^{2+}$ signals in spines of hippocampal neurons. J Neurosci 20:1791-1799.

Krsmanovic LZ, Stojilkovic SS, Merelli F, Dufour SM, Virmani MA, Catt KJ (1992) Calcium signaling and episodic secretion of gonadotropinreleasing hormone in hypothalamic neurons. Proc Natl Acad Sci USA 89:8462-8466.

Kuehl-Kovarik MC, Pouliot WA, Halterman GL, Handa RJ, Dudek FE, Partin KM (2002) Episodic bursting activity and response to excitatory amino acids in acutely dissociated gonadotropin-releasing hormone neurons genetically targeted with green fluorescent protein. J Neurosci 22:2313-2322.

Mak DO, McBride S, Foskett JK (1998) Inositol 1,4,5-trisphosphate receptor $\mathrm{Ca}^{2+}$ channel by ligand tuning of $\mathrm{Ca}^{2+}$ inhibition. Proc Natl Acad Sci USA 95:15821-15825.

Maletic-Savatic M, Malinow R, Svoboda K (1999) Rapid dendritic morphogenesis in CA1 hippocampal dendrites induced by synaptic activity. Science 283:1923-1927.

Markram H, Helm PJ, Sakmann B (1995) Dendritic calcium transients evoked by single back-propagating action potentials in rat neocortical pyramidal neurons. J Physiol (Lond) 485:1-20.

Martinez de la Escalera G, Choi AL, Weiner RI (1992) Generation and synchronization of gonadotropin-releasing hormone $(\mathrm{GnRH})$ pulses: intrinsic properties of the GT1-1 GnRH neuronal cell line. Proc Natl Acad Sci USA 89:1852-1855.

Merriam GR, Wachter KW (1982) Algorithms for the study of episodic hormone secretion. Am J Physiol 243:E310-E318. 
Miyawaki A (2005) Innovations in the imaging of brain functions using fluorescent proteins. Neuron 48:189-199.

Moenter SM, DeFazio AR, Pitts GR, Nunemaker CS (2003) Mechanisms underlying episodic gonadotropin-releasing hormone secretion. Front Neuroendocrinol 24:79-93.

Moore Jr JP, Wray S (2000) Luteinizing hormone-releasing hormone (LHRH) biosynthesis and secretion in embryonic LHRH. Endocrinology 141:4486-4495.

Moore Jr JP, Shang E, Wray S (2002) In situ GABAergic modulation of synchronous gonadotropin releasing hormone-1 neuronal activity. J Neurosci 22:8932-8941.

Nagai T, Sawano A, Park ES, Miyawaki A (2001) Circularly permuted green fluorescent proteins engineered to sense $\mathrm{Ca}^{2+}$. Proc Natl Acad Sci USA 98:3197-3202.

Nakamura T, Barbara JG, Nakamura K, Ross WN (1999) Synergistic release of $\mathrm{Ca}^{2+}$ from IP3-sensitive stores evoked by synaptic activation of mGluRs paired with backpropagating action potentials. Neuron 24:727-737.

Nakamura T, Lasser-Ross N, Nakamura K, Ross WN (2002) Spatial segregation and interaction of calcium signalling mechanisms in rat hippocampal CA1 pyramidal neurons. J Physiol (Lond) 543:465-480.

Nett WJ, Oloff SH, McCarthy KD (2002) Hippocampal astrocytes in situ exhibit calcium oscillations that occur independent of neuronal activity. J Neurophysiol 87:528-537.

Pape JR, Skynner MJ, Allen ND, Herbison AE (1999) Transgenics identify distal $5^{\prime}$ - and $3^{\prime}$-sequences specifying gonadotropin-releasing hormone expression in adult mice. Mol Endocrinol 13:2203-2211.

Parri HR, Crunelli V (2003) The role of $\mathrm{Ca}^{2+}$ in the generation of spontaneous astrocytic $\mathrm{Ca}^{2+}$ oscillations. Neuroscience 120:979-992.

Parri HR, Gould TM, Crunelli V (2001) Spontaneous astrocytic $\mathrm{Ca}^{2+}$ oscillations in situ drive NMDAR-mediated neuronal excitation. Nat Neurosci 4:803-812.

Peppiatt CM, Collins TJ, Mackenzie L, Conway SJ, Holmes AB, Bootman MD, Berridge MJ, Seo JT, Roderick HL (2003) 2-Aminoethoxydiphenyl borate (2-APB) antagonises inositol 1,4,5-trisphosphate-induced calcium release, inhibits calcium pumps and has a use-dependent and slowly reversible action on store-operated calcium entry channels. Cell Calcium 34:97-108.

Perez JF, Sanderson MJ (2005a) The frequency of calcium oscillations induced by $5-\mathrm{HT}, \mathrm{ACH}$, and $\mathrm{KCl}$ determine the contraction of smooth muscle cells of intrapulmonary bronchioles. J Gen Physiol 125:535-553.

Perez JF, Sanderson MJ (2005b) The contraction of smooth muscle cells of intrapulmonary arterioles is determined by the frequency of $\mathrm{Ca}^{2+}$ oscillations induced by 5-HT and KCl. J Gen Physiol 125:555-567.

Pologruto TA, Yasuda R, Svoboda K (2004) Monitoring neural activity and $\left[\mathrm{Ca}^{2+}\right]$ with genetically encoded $\mathrm{Ca}^{2+}$ indicators. J Neurosci 24:9572-9579.

Ross WN, Nakamura T, Watanabe S, Larkum M, Lasser-Ross N (2005) Synaptically activated $\mathrm{Ca}^{2+}$ release from internal stores in CNS neurons. Cell Mol Neurobiol 25:283-295.

Sabatini BL, Oertner TG, Svoboda K (2002) The life cycle of $\mathrm{Ca}^{2+}$ ions in dendritic spines. Neuron 33:439-452.

Shimozono S, Fukano T, Nagai T, Kirino Y, Mizuno H, Miyawaki A (2002) Confocal imaging of subcellular $\mathrm{Ca}^{2+}$ concentrations using a dualexcitation ratiometric indicator based on green fluorescent protein. Sci STKE 2002:PL4.

Shimshek DR, Kim J, Hubner MR, Spergel DJ, Buchholz F, Casanova E, Stewart AF, Seeburg PH, Sprengel R (2002) Codon-improved Cre recombinase (iCre) expression in the mouse. Genesis 32:19-26.

Shimshek DR, Bus T, Kim J, Mihaljevic A, Mack V, Seeburg PH, Sprengel R,
Schaefer AT (2005) Enhanced odor discrimination and impaired olfactory memory by spatially controlled switch of AMPA receptors. PLoS Biol 3:e354.

Sim JA, Skynner MJ, Herbison AE (2001) Heterogeneity in the basic membrane properties of postnatal gonadotropin-releasing hormone neurons in the mouse. J Neurosci 21:1067-1075.

Skynner MJ, Slater R, Sim JA, Allen ND, Herbison AE (1999) Promoter transgenics reveal multiple gonadotropin-releasing hormone-Iexpressing cell populations of different embryological origin in mouse brain. J Neurosci 19:5955-5966.

Sneyd J, Tsaneva-Atanasova K, Yule DI, Thompson JL, Shuttleworth TJ (2004) Control of calcium oscillations by membrane fluxes. Proc Natl Acad Sci USA 101:1392-1396.

Spergel DJ, Krsmanovic LZ, Stojilkovic SS, Catt KJ (1995) L-type Ca ${ }^{2+}$ channels mediate joint modulation by gamma-amino-butyric acid and glutamate of $\left[\mathrm{Ca}^{2+}\right]_{\mathrm{i}}$ and neuropeptide secretion in immortalized gonadodropinreleasing hormone neurons. Neuroendocrinology 61:499-508.

Spergel DJ, Kruth U, Hanley DF, Sprengel R, Seeburg PH (1999) GABAand glutamate-activated channels in green fluorescent protein-tagged gonadotropin-releasing hormone neurons in transgenic mice. J Neurosci 19:2037-2050.

Suter KJ, Song WJ, Sampson TL, Wuarin JP, Saunders JT, Dudek FE, Moenter SM (2000) Genetic targeting of green fluorescent protein to gonadotropinreleasing hormone neurons: characterization of whole-cell electrophysiological properties and morphology. Endocrinology 141:412-419.

Terasawa E (2001) Luteinizing hormone-releasing hormone (LHRH) neurons: mechanism of pulsatile LHRH release. Vitam Horm 63:91-129.

Terasawa E, Schanhofer WK, Keen KL, Luchansky L (1999) Intracellular $\mathrm{Ca}^{2+}$ oscillations in luteinizing hormone-releasing hormone neurons derived from the embryonic olfactory placode of the rhesus monkey. J Neurosci 19:5898-5909.

Tsien RY (2003) Imagining imaging's future. Nat Rev Mol Cell Biol Suppl:SS16-SS21.

Uhlen P (2004) Spectral analysis of calcium oscillations. Sci STKE 2004:pl15.

Van Goor F, Krsmanovic LZ, Catt KJ, Stojilkovic SS (1999a) Coordinate regulation of gonadotropin-releasing hormone neuronal firing patterns by cytosolic calcium and store depletion. Proc Natl Acad Sci USA 96:4101-4106.

Van Goor F, Krsmanovic LZ, Catt KJ, Stojilkovic SS (1999b) Control of action potential-driven calcium influx in GT1 neurons by the activation status of sodium and calcium channels. Mol Endocrinol 13:587-603.

Verkhratsky A (2005) Physiology and pathophysiology of the calcium store in the endoplasmic reticulum of neurons. Physiol Rev 85:201-279.

Wetsel WC, Valenca MM, Merchenthaler I, Liposits Z, Lopez FJ, Weiner RI, Mellon PL, Negro-Vilar A (1992) Intrinsic pulsatile secretory activity of immortalized luteinizing hormone-releasing hormone-secreting neurons. Proc Natl Acad Sci USA 89:4149-4153.

Wintermantel TM, Campbell RE, Porteous R, Bock D, Grone HJ, Todman MG, Korach KS, Greiner E, Perez CA, Schutz G, Herbison AE (2006) Definition of estrogen receptor pathway critical for estrogen positive feedback to gonadotropin-releasing hormone neurons and fertility. Neuron 52:271-280.

Yoon H, Enquist LW, Dulac C (2005) Olfactory inputs to hypothalamic neurons controlling reproduction and fertility. Cell 123:669-682.

Yuste R, Majewska A, Cash SS, Denk W (1999) Mechanisms of calcium influx into hippocampal spines: heterogeneity among spines, coincidence detection by NMDA receptors, and optical quantal analysis. J Neurosci 19:1976-1987. 